\title{
ANALISIS YURIDIS MENGENAI SISTEM ZONASI DALAM PENERIMAAN PESERTA DIDIK BARU
}

\author{
Tri Mulyani, Dewi Tuti Muryati \\ Fakultas Hukum, Universitas Semarang, Semarang \\ trimulyani@usm.ac.id
}

\begin{abstract}
ABSTRAK
Tujuan dalam penelitian ini adalah pengaturan tentang sistem zonasi dalam Penerimaan Peserta Didik Baru berdasarkan Permendikbud RI Nomor 20 Tahun 2019 beserta implikasinya. Metode penelitian yang dipergunakan diantaranya adalah tipe penelitian yuridis normatif, dengan pendekatan perundang - undangan dan pendekatan konsep, spesifikasi penelitan diskriptif analitis, pengumpulan data dengan studi kepustakaan, dan analis data kualitatif. Hasil penelitian menunjukan bahwa pengaturan sistem zonasi dalam Penerimaan Peserta Didik Baru yang diatur berdasarkan Permendikbud RI No. 20 Tahun 2019, bertentangan dengan peraturan diatasnya yaitu PP RI No. 13 Tahun 2015 yang menetapkan bahwa hasil ujian nasional digunakan sebagai dasar untuk pertimbangan seleksi masuk jenjang pendidikan berikutnya, yang mana peraturan pemerintah ini merupakan penjabaran dari UU RI No. 20 Tahun, sehingga berdasarkan Stufenbautheory dari Hans Kelsen yang diterjemahkan di Indonesia melalui UU RI No. 12 Tahun 2011 maka Permendikbud RI No. 20 Tahun 2019 harus dicabut, atau perlu dikaji ulang dan disesuaikan dengan peraturan diatasnya agar tercipta harmonisasi peraturan perundang undangan. Adapun implikasinya bagi calon peserta didik, meliputi 2 (dua) hal yaitu: Pertama, implikasi positif antara lain calon peserta didik baru memperoleh akses pendidikan dan terjadinya pemerataan pendidikan; Kedua, implikasi negatif antara lain calon peserta didik baru tidak bisa memilih sekolah yang sesuai harapan, dan bagi calon peserta didik yang berprestasi kurang mendapat penghargaan.
\end{abstract}

Kata Kunci : zonasi; penerimaan; peserta didik baru 
e-ISSN : 2621-4105

\title{
JURIDICAL ANALYSIS OF ZONATION SYSTEMS IN RECEIVING NEW STUDENTS
}

\author{
Tri Mulyani, Dewi Tuti Muryati \\ Fakultas Hukum, Universitas Semarang, Semarang \\ trimulyani@usm.ac.id
}

\begin{abstract}
The purpose of this study is the regulation of the zoning system in the Acceptance of New Students based on the Minister of Education Regulation No. 20 of 2019 along with its implications. The research methods used include normative juridical research types, with the statutory approach and concept approach, descriptive analytical research specifications, data collection with literature studies, and qualitative data analysts. The results showed that the zoning system arrangement in the Acceptance of New Students which was regulated based on the Republic of Indonesia Minister of Education Regulation No. 20 of 2019, contrary to the above regulations namely RI Regulation No. 13 of 2015 which stipulates that the results of the national examination are used as a basis for consideration of the next level of education selection, which is a government regulation which is an elaboration of Law RI No. 20 years, so based on Stufenbautheory from Hans Kelsen which is translated in Indonesia through RI Law No. 12 of 2011 the Republic of Indonesia Minister of Education Regulation No. 20 of 2019 must be revoked, or it needs to be reviewed and adjusted to the regulations above to create harmonization of laws and regulations. The implications for prospective students include 2 (two) things, namely: First, the positive implications include prospective new students getting access to education and the occurrence of educational equity; Second, the negative implications include prospective new students not being able to choose a school that is in line with expectations, and for prospective students who excel are lacking appreciation.
\end{abstract}

Keywords: zoning; reception; new learners 


\section{A. PENDAHULUAN}

Berkembangnya suatu negara tentu didukung dengan sumber daya manusia yang memadai. Selanjutnya sumber daya manusia yang memadai ini, tentu tidak terlepas dari berkembangnya bidang pendidikan. Untuk itu pemerintah memberikan jaminan pendidikan kepada setiap warga negaranya, agar nantinya negara mampu bersaing dengan negara-negara lain. Jaminan pendidikan ini, di Indonesia dituangkan dalam Pembukaan Undang-Undang Dasar Negara Republik Indonesia Tahun 1945 tepatnya pada Pasal 28C ayat (1) yaitu "Setiap orang berhak mengembangkan diri melalui pemenuhan kebutuhan dasarnya, berhak mendapatkan pendidikan dan memperoleh manfaat dari ilmu pengetahuan dan teknologi, seni, dan budaya, demi meningkatkan kualitas hidupnya dan demi kesejahteraan umat manusia”. Selanjutnya dijamin juga Pasal 31 Ayat (1) Undang-Undang Dasar Negara Republik Tahun 1945 yaitu "Setiap warga negara berhak mendapatkan pendidikan”, lebih lanjut dalam ayat (2) disebutkan bahwa "Setiap warga negara wajib mengikuti pendidikan dasar dan wajib membiayainya". Berdasarkan ketentuan tersebut dapat dikatakan bahwa pendidikan merupakan hak dasar yang dimiliki oleh setiap warga negara, dan merupakan suatu kewajiban bagi pemerintah untuk mengupayakannya.

Dalam bahasa Inggris, kata pendidikan disebut juga dengan Education di mana secara etimologis kata tersebut berasal dari bahasa Latin, yakni Eductum. Kata Eductum ini terdiri dari dua kata, yaitu $E$ yang artinya suatu perkembangan dari dalam keluar, dan Duco yang artinya sedang berkembang. Sehingga secara etimologis arti pendidikan adalah suatu proses mengembangkan kemampuan diri sendiri dan kekuatan individu. ${ }^{2}$ Menurut Prof. H. Mahmud Yunus menyatakan bahwa:

"Pendidikan ialah suatu usaha yang dengan sengaja dipilih untuk dapat mempengaruhi dan membantu anak yang bertujuan untuk dapat

\footnotetext{
${ }^{1}$ Undang-Undang Dasar Negara Republik Tahun 1945, Pasal 31 Ayat (1) dan Ayat (2).

${ }^{2}$ Guru Pendidikan. Pengertian Pendidikan Menurut Para Ahli: Tujuan, Fungsi dan Jenisnya Terlengkap (https://seputarilmu.com/2019/01/pengertian-pendidikan-menurut-paraahli.html/,diakses tanggal 06 September 2019), 2019.
} 
meningkatkan ilmu pengetahuan, jasmani dan akhlak sehingga secara perlahan bisa mengantarkan anak kepada tujuan dan cita-citanya yang paling tinggi. Supaya memperoleh suatu kehidupan yang bahagia dan apa yang dilakukanya dapat bermanfaat bagi dirinya sendiri, masyarakat, bangsa, negara dan agamanya". 3

Selanjutnya berdasarkan Pasal 1 Angka 1, Undang-Undang RI Nomor 20 Tahun 2003 tentang Sistem Pendidikan Nasional, dijelaskan bahwa:

"Pendidikan adalah usaha sadar dan terencana untuk mewujudkan suasana belajar dan proses pembelajaran agar peserta didik secara aktif mengembangkan potensi dirinya untuk memiliki kekuatan spiritual keagamaan, pengendalian diri, kepribadian, kecerdasan, akhlak mulia, serta keterampilan yang diperlukan dirinya, masyarakat, bangsa dan negara. ${ }^{4}$

Selanjutnya, dalam bidang pendidikan, unsur yang paling penting yang harus ada didalamnya adalah Pendidik, Peserta Didik, serta sarana dan prasarana. Dari ketiga unsur tersebut yang sangat penting yang wajib adalah peserta didik. Tanpa ada peserta didik, maka tidak akan terjadi proses belajar mengajar. Peserta didik adalah anggota masyarakat yang berusaha mengembangkan potensi diri melalui proses pembelajaran yang tersedia pada jalur, jenjang, dan jenis pendidikan tertentu. ${ }^{5}$ Bagi anggota masyarakat yang ingin mengembangkan potensi dirinya melalui jenjang pendidikan, maka mereka harus melalui proses pendaftaran Penerimaan Peserta Didik Baru terlebih dahulu.

Peserta didik dapat dipahami sebagai anggota masyarakat yang berusaha mengembangkan potensi diri melalui proses pembelajaran, orang yang mengharapkan mendapat pelayanan pendidikan sesuai dengan bakat minat dan kemampuannya agar tumbuh dan berkembang dengan baik serta mempunyai kekuasaan dalam menerima pelajaran. Peserta didik mempunyai sebutan yang berbeda-beda dalam berbagai jenjang, pada taman kanak-kanak disebut anak didik, pada jenjang pendidikan dasar dan menengah disebut dengan peserta didik,

\footnotetext{
${ }^{3}$ Ibid.

${ }^{4}$ Undang-Undang RI Nomor 20 Tahun 2003 tentang Sistem Pendidikan Nasional, Pasal 1 Angka 1

${ }^{5}$ Ibid., Pasal 1 Angka 4.
} 
dan pada jenjang pendidikan tinggi disebut maha peserta didik. ${ }^{6}$ Penerimaan Peserta Didik Baru yang familiar dengan akronim PPDB adalah penerimaan peserta didik untuk jenjang taman kanak-kanak, sekolah dasar dan sekolah menengah pertama yang dilaksanakan pada awal tahun pelajaran baru. PPDB jenjang SMP dilakukan secara online, prioritasnya adalah anak usia 12-15 tahun. ${ }^{7}$

Sehubungan dengan hal tersebut di atas, penyelenggaraan pendidikan diselenggarakan dengan prinsip demokratis dan berkeadilan serta tidak diskriminatif yang diatur dalam Undang-Undang Nomor 20 tahun 2003 tentang Sistem Pendidikan Nasional tepatnya Pasal 4 ayat (1). Sebagai peraturan pelaksana dari Undang-Undang Nomor 20 Tahun 2003 tentang Sistem Pendidikan Nasional, maka dalam hal penyelenggaraan pendidikan khususnya dalam hal pendaftaran Penerimaan Peserta Didik Baru, dikeluarkanlah Peraturan Menteri Pendidikan dan Kebudayaan Republik Indonesia Nomor 20 Tahun 2019 tentang Perubahan Atas Peraturan Menteri Pendidikan Dan Kebudayaan Nomor 51 Tahun 2018 tentang Penerimaan Peserta Didik Baru Pada Taman Kanak-Kanak, Sekolah Dasar, Sekolah Menengah Pertama, Sekolah Menengah Atas, Dan Sekolah Menengah Kejuruan. Peraturan menteri ini adalah penjabaran dari UndangUndang RI Nomor 20 Tahun 2003 tentang Sistem Pendidikan Nasional. Terdapat 3 Peraturan Menteri Pendidikan dan Kebudayaan Republik Indonesia yang pernah berlaku yaitu:

a. Peraturan Menteri Pendidikan Dan Kebudayaan Republik Indonesia Nomor 17 Tahun 2017 tentang Penerimaan Peserta Didik Baru Pada Taman KanakKanak, Sekolah Dasar, Sekolah Menengah Pertama, Sekolah Menengah Atas, Sekolah Menengah Kejuruan, Atau Bentuk Lain Yang Sederajat.

b. Peraturan Menteri Pendidikan Dan Kebudayaan Republik Indonesia Nomor 14 Tahun 2018 tentang Penerimaan Peserta Didik Baru Pada Taman Kanak-

${ }^{6}$ Muhamad Khoirul Umam, Peningkatan Mutu PendidikanMelalui Manajemen Peserta Didik, Jurnal al-Hikmah Vol. 6 no. 2 Oktober 2018, STAI Badrus Sholeh Kediri, 2018, Kediri, hal 62

${ }^{7}$ Dian Purwanti, Ira Irawati, Josy Adiwisastra, Efektivitas Kebijakan Penerimaan Peserta Didik Baru Sistem Zonasi Bagi Siswa Rawan Melanjutkan Pendidikan, Jurnal Ilmiah Ilmu Administrasi Negara Dinamika Vol 5 No 4, Universitas Galuh, 2019, Ciamis, hal 1. DOI: http://dx.doi.org/10.25157/dinamika.v5i4.1737 
Kanak, Sekolah Dasar, Sekolah Menengah Pertama, Sekolah Menengah Atas, Sekolah Menengah Kejuruan, Atau Bentuk Lain Yang Sederajat.

c. Peraturan Menteri Pendidikan Dan Kebudayaan Republik Indonesia Nomor 51 Tahun 2018 tentang Penerimaan Peserta Didik Baru Pada Taman KanakKanak, Sekolah Dasar, Sekolah Menengah Pertama, Sekolah Menengah Atas, Dan Sekolah Menengah Kejuruan.

d. Peraturan Menteri Pendidikan Dan Kebudayaan Republik Indonesia Nomor 20 Tahun 2019 tentang Perubahan Atas Peraturan Menteri Pendidikan Dan Kebudayaan Nomor 51 Tahun 2018 tentang Penerimaan Peserta Didik Baru Pada Taman Kanak-Kanak, Sekolah Dasar, Sekolah Menengah Pertama, Sekolah Menengah Atas, Dan Sekolah Menengah Kejuruan.

Calon peserta didik hanya dapat memilih 1 jalur dari 3 jalur pendaftaran PPDB dalam satu zonasi. Selain melakukan pendaftaran PPDB melalui jalur zonasi sesuai dengan domisili dalam zonasi yang telah ditetapkan, calon peserta didik dapat melakukan pendaftaran PPDB melalui jalur prestasi di luar zonasi domisili peserta didik. Sekolah yang diselenggarakan oleh Pemerintah Daerah dilarang membuka jalur pendaftaran PPDB selain yang diatur dalam Permendikbud Nomor 20 Tahun 2019 ini.

Bertitik tolak dari ketentuan tersebut di atas, sesungguhnya pendaftaran PPDB, bertujuan untuk mendorong peningkatan akses layanan pendidikan bagi masyarakkat yang akan mengembangkan potensi dirinya dalam jenjang pendidikannya masing-masing secara non diskriminatif, transparan, objektif, akuntabel dan berkeadilan, baik di jenjang TK, SD, SMP, SMA, dan SMK. Dalam ketentuan tersebut dapat dikatakan bahwa dalam hal Penerimaan Peserta Didik Baru (PPDB) tahun 2019 ini menggunakan jalur zonasi.

Penerapan sistem zonasi ini mengharuskan calon peserta didik untuk menempuh pendidikan di sekolah yang memiliki radius terdekat dari domisilinya masing-masing. Peserta didik bisa memiliki opsi maksimal 3 (tiga) sekolah, dengan catatan sekolah tersebut masih memiliki slot siswa dan berada dalam wilayah zonasi siswa tersebut. Melalui sistem zonasi, seleksi calon peserta didik baru memprioritaskan jarak tempat tinggal terdekat ke sekolah dalam zonasi yang 
ditetapkan dengan penghitungan berdasarkan jarak tempuh dari Kantor Desa/Kelurahan menuju ke sekolah. Apabila jarak tempat tinggal sama, maka yang diprioritaskan adalah calon peserta didik yang mendaftar lebih awal.

Artinya bahwa sistem zonasi ini dapat menyebabkan calon peserta didik yang bernilai tinggi tidak dapat diterima di sekolah yang diinginkan karena berdomisili jauh dari sekolah tersebut. Calon peserta didik merasa kesulitan untuk masuk ke sekolah terbaik karena berada di zona yang berbeda yang padat populasinya, sehingga terpaksa mendftar ke sekolah di zona terdekat yang mutunya kurang baik. Sebaliknya banyak sekolah favorit yang berada di lokasi tidak padat penduduk, sehingga tidak dapat memenuhi kuota.

Prosedur zonasi dalam PPDB ini menuai permasalahan dalam pelaksanaanya di berbagai daerah. Dapat diambil contoh kasus di daerah Kabupaten Banyumas. Dengan kuota jalur zonasi minimal $80 \%$ prestasi maksimal $15 \%$ dan jalur perpindahan tugas orang tua/wali paling banyak 5\% dari daya tampung sekolah, menyebabkan keresahan bagi anggota masyarakat. Artinya bahwa sistem zonasi ini hanya mengakses maksimal $15 \%$ untuk siswa berprestasi, sehingga kasus yang terjadi di daerah Kabupaten Banyumas ini harus kecewa karena dengan peraturan ini, dirinya sudah merasa berada di luar zonasi (5,5 KM) meskipun nilainya cukup tinggi. Hal tersebut dipertegas Humas Panitia Penerimaan Peserta Didik Baru, SMP Negeri 2 Purwokerto, Agus Widodo, bahwa banyak sekali yang mendaftar, namun sayangnya harus menunggu kuota 80 persen zonasi terpenuhi.

Dapat diambil contoh juga di daerah Indramayu. Dengan berlakunya sistem zonasi menyebabkan tidak terpenuhinya kuota tiap sekolah. Di Indramayu terdapat 90 sekolahan negeri setingkat SMP, 10\% persennya belum terpenuhi kuota. Dicontohkan di Desa Sukasari, Kecamatan Arahan. Sekolah yang ada di desa tersebut jaraknya cukup jauh dari Kecamatan Arahan. Ada 28 siswa tidak menjangkau zonasi, akhirnya dimasukkan ke sekolah yang ada di Lohbener karena jaraknya lebih dekat meskipun beda zonasi. ${ }^{8}$

${ }^{8}$ Gelar Gandarasa. PPDB 2019, Belum Semua Sekolah Kuotanya Terpenuhi 
Dari fenomena ini artinya bahwa sistem zonasi belum dapat mengakomodasi semua calon peserta didik baru. Bahkan calon peserta didik yang tinggal diarea blank spot (tidak terjangkau zona sekolah) kesulitan masuk sekolah negeri. Terkait ini Ombudsman Republik Indonesia Perwakilan DIY banyak menerima pengaduan terkait calon peserta didik blank spot yang akhirnya harus bersekolah di swasta karena tidak terakomodasi di sekolah negeri. ${ }^{9}$ Oleh karena itu, dalam penelitian ini, secara yuridis normatif berusaha akan mengkajinya dengan menentukan topik kajian pada analisis pengaturan sistem zonasi dan implikasinya bagi calon peserta didik.

\section{B. PERUMUSAN MASALAH}

Permasalahan yang dikaji akan difokuskan pada 2 (dua) hal, yaitu

1. Bagaimana analisis pengaturan tentang sistem zonasi dalam Penerimaan Peserta Didik Baru (PPDB) berdasarkan Permendikbud RI Nomor 20 Tahun $2019 ?$

2. Apa implikasinya bagi Calon Peserta Didik mengenai pengaturan tentang sistem zonasi dalam Penerimaan Peserta Didik Baru (PPDB) berdasarkan Permendikbud RI Nomor 20 Tahun 2019?

\section{METODE PENELITIAN}

\section{Tipe Penelitian}

Tipe penelitian hukum yang digunakan adalah penelitian yuridis normatif, yakni penelitian yang difokuskan untuk mengkaji penerapan kaedah-kaedah atau norma-norma hukum positif. ${ }^{10}$ Tipe ini dipergunakan, mengingat bahwa obyek penelitian ini adalah pengaturan dan implikasinya bagi Calon Peserta Didik mengenai pengaturan sistem zonasi dalam PPDB Berdasarkan Permendikbud RI Nomor 20 Tahun 2019.

\section{Metode Pendekatan}

\footnotetext{
(https://www.pikiran-rakyat.com/pendidikan/2019/06/25/ppdb-2019-belum-semua-sekolahkuotanya-terpenuhi/, diakses 05 September 2019), 2019.

9 Dinar Wahyuni. Pro dan Kontra Sistem Zonasi Penerimaan Peserta Didik Baru Tahun Ajaran 2018/2019. Jurnal Info Singkat, Vol. X, No.14/II/Puslit/Juli 2018, hal 2

${ }^{10}$ Johnny Ibrahim, Teori Dan Metodologi Penelitian Hukum Normatif , Edisi Revisi (Malang: Bayumedia Publishing, 2005), hal 295
} 
Metode pendekatan yang digunakan ada 3 (tiga) yaitu pendekatan perundang-undangan digunakan untuk meneliti aturan terkait pengaturan dan implikasinya bagi Calon Peserta Didik mengenai pengaturan sistem zonasi dalam PPDB Berdasarkan Permendikbud RI Nomor 20 Tahun 2019; pendekatan konsep digunakan untuk memahami mengenai konsep-konsep sistem zonasi; dan pendekatan analitis digunakan untuk mengetahui makna yang dikandung oleh istilah-istilah yang digunakan dalam peraturan perundang-undangan secara konsepsional, sekaligus mengetahui penerapannya dalam praktik-praktik, yang dilakukan dengan 2 cara yaitu berusaha memperoleh makna baru dan menguji istilah-istilah hukum dalam praktik melalui analisis Permendikbud RI Nomor 20 Tahun 2019.

\section{Spesifikasi penelitian}

Spesifikasi penelitian yang akan dipergunakan adalah diskriptif analitis, yaitu menggambarkan peraturan perundang-undangan yang berlaku sebagai hukum positif dikaitkan dengan teori hukum dan praktek pelaksanaan hukum positif dalam masyarakat. ${ }^{11}$ Dengan demikian, untuk mendapatkan gambaran yang jelas mengenai mengenai pengaturan dan implikasi tentang sistem zonasi dalam PPDB Berdasarkan Permendikbud RI Nomor 20 Tahun 2019, maka dalam penelitian ini akan diuraikan hasil-hasil penelitian sesuai dengan permasalahan dan tujuan yang akan dicapai serta menganalisisnya dari segi peraturan yang berlaku terkait dengan sistem pendidikan

\section{Metode Pengumpulan Data}

Berdasarkan tipe penelitian yang dipergunakan dalam penelitian ini adalah yuridis normatif, maka untuk mendapatkan data yang objektif, jenis data yang dibutuhkan adalah data sekunder. Data ini diambil dengan cara penelitian kepustakaan. Data sekunder yang diambil meliputi bahan hukum primer dan bahan hukum sekunder, yaitu sebagai berikut:

${ }^{11}$ Bambang Sunggono, Metode Penelitian Hukum (Jakarta: PT. Raja Grafindo Persada, 2002), hal 36. 


\section{PEMBAHASAN}

\section{Analisis Pengaturan Tentang Sistem Zonasi Dalam Penerimaan Peserta Didik Baru Berdasarkan Permendikbud RI Nomor 20 Tahun 2019.}

Dalam Permendikbud No 20 Tahun 2019, mengatur tentang PPDB, dengan ketentuan:

\section{a. Pelaksanaan}

Sekolah yang diselenggarakan oleh Pemerintah Daerah melaksanakan PPDB pada bulan Mei setiap tahun. Pelaksanaan PPDB dimulai dari tahap:

1) Pengumuman

Pengumuman pendaftaran penerimaan calon peserta didik baru pada Sekolah yang bersangkutan dilakukan secara terbuka. Pengumuman pendaftaran penerimaan calon peserta didik baru paling sedikit memuat informasi:

2) Pendaftaran;

3) Seleksi sesuai dengan jalur pendaftaran;

4) Pengumuman penetapan peserta didik baru;

Pengumuman penetapan peserta didik baru dilakukan sesuai dengan jalur pendaftaran dalam PPDB dan Penetapan peserta didik baru dilakukan berdasarkan hasil rapat dewan guru yang dipimpin oleh kepala Sekolah dan ditetapkan melalui keputusan kepala Sekolah

5) Daftar ulang.

Khusus untuk SMK dalam tahap pelaksanaan PPDB dapat melakukan proses seleksi khusus yang dilakukan sebelum tahap pengumuman penetapan peserta didik baru.

PPDB dilaksanakan dengan menggunakan mekanisme dalam jaringan (daring), namun dalam hal tidak tersedia fasilitas jaringan, maka PPDB dapat dilaksanakan melalui mekanisme luar jaringan (luring). ${ }^{12}$

\section{b. Persyaratan}

\footnotetext{
${ }^{12}$ Ibid., Pasal 5
} 
Calon peserta didik yang akan melakukan pendaftaran harus memenuhi berbagai persyaratan antara lain sebagai berikut: ${ }^{13}$

1) Persyaratan calon peserta didik baru TK

Persyaratan calon peserta didik baru pada jenjang TK adalah sebagai berikut:

a) Berusia 4 (empat) tahun sampai dengan 5 (lima) tahun untuk kelompok A; dan

b) Berusia 5 (lima) tahun sampai dengan 6 (enam) tahun untuk kelompok B.

2) Persyaratan calon peserta didik baru kelas 1 (satu) SD

Persyaratan calon peserta didik baru pada jenjang kelas 1 (satu) SD: ${ }^{14}$

a) Berusia 7 (tujuh) tahun; atau

b) Paling rendah 6 (enam) tahun pada tanggal 1 Juli tahun berjalan.

3) Persyaratan calon peserta didik baru kelas 7 (tujuh) SMP

Persyaratan calon peserta didik baru pada jenjang kelas kelas 7 (tujuh) SMP: ${ }^{15}$

a) Berusia paling tinggi 15 (lima belas) tahun pada tanggal 1 Juli tahun berjalan; dan

b) Memiliki ijazah atau surat tanda tamat belajar SD atau bentuk lain yang sederajat.

4) Persyaratan calon peserta didik baru kelas 10 (sepuluh) SMA atau SMK

\section{c. Jalur Pendaftaran}

Pendaftaran PPDB dilaksanakan melalui jalur antara lain sebagai berikut: ${ }^{16}$

1) Zonasi

Jalur zonasi paling sedikit $80 \%$ dari daya tampung Sekolah. Kuota paling sedikit $80 \%$ dalam jalur zonasi ini termasuk didalamnya adalah kuota bagi:

a) Peserta didik tidak mampu

\footnotetext{
${ }^{13}$ Ibid., Pasal 6

${ }^{14}$ Ibid., Pasal 7

15 Ibid., Pasal 8

${ }^{16}$ Ibid., Pasal 16 sampai dengan Pasal 21
} 
Peserta didik baru yang berasal dari keluarga ekonomi tidak mampu harus dibuktikan dengan bukti keikutsertaan Peserta Didik dalam program penanganan keluarga tidak mampu dari Pemerintah Pusat atau Pemerintah Daerah.

b) Anak penyandang disabilitas pada Sekolah yang menyelenggarakan layanan inklusif.

Dalam melaksanakan PPDB melalui jalur zonasi dengan kuota paling sedikit $80 \%$ ini, Sekolah yang diselenggarakan oleh Pemerintah Daerah wajib menerima calon peserta didik yang berdomisili sesuai zona yang ditetapkan Pemerintah Daerah. Domisili calon peserta didik berdasarkan alamat pada kartu keluarga yang diterbitkan paling singkat 1 (satu) tahun sebelum pelaksanaan PPDB.

Kartu keluarga dapat diganti dengan surat keterangan domisili dari rukun tetangga atau rukun warga yang dilegalisir oleh lurah/kepala desa setempat yang menerangkan bahwa peserta didik yang bersangkutan telah berdomisili paling singkat 1 tahun sejak diterbitkannya surat keterangan domisili. Sekolah memprioritaskan peserta didik yang memiliki kartu keluarga atau surat keterangan domisili dalam satu wilayah kabupaten/kota yang sama dengan Sekolah asal.

SMA/SMK yang diselenggarakan oleh Pemerintah Daerah wajib menerima Peserta didik yang berasal dari keluarga tidak mampu paling sedikit $20 \%$ dari jumlah daya tampung.

Penetapan zonasi dilakukan pada setiap jenjang oleh Pemerintah Daerah sesuai dengan kewenangannya, dengan prinsip mendekatkan domisili peserta didik dengan Sekolah dengan memperhatikan jumlah ketersediaan daya tampung yang disesuaikan dengan ketersediaan jumlah anak usia Sekolah pada setiap jenjang di daerah tersebut. Dalam hal ini Pemerintah Daerah wajib memastikan semua wilayah administrasi masuk dalam penetapan zonasi sesuai dengan jenjang pendidikan dan memastikan bahwa semua Sekolah yang 
diselenggarakan oleh Pemerintah Daerah dalam proses PPDB telah menerima peserta didik dalam zonasi yang telah ditetapkan.

2) Prestasi

Jalur prestasi paling banyak 15\% dari daya tampung Sekolah, ditentukan berdasarkan:

a) Nilai ujian Sekolah berstandar nasional atau UN; dan/atau

b) Hasil perlombaan dan/atau penghargaan di bidang akademik maupun nonakademik pada tingkat internasional, tingkat nasional, tingkat provinsi, dan/atau tingkat kabupaten/kota.

Peserta didik yang masuk melalui jalur Prestasi merupakan peserta didik yang berdomisili di luar zonasi Sekolah yang bersangkutan.

3) Perpindahan tugas orang tua/wali.

Jalur perpindahan tugas orang tua/wali paling banyak 5\% dari daya tampung Sekolah. Jalur ini ditujukan bagi calon peserta didik yang berdomisili di luar zonasi Sekolah yang bersangkutan. Perpindahan tugas ini harus dibuktikan dengan surat penugasan dari instansi, lembaga, kantor, atau perusahaan yang mempekerjakan. Dalam hal jalur perpindahan tugas orang tua/wali tidak terpenuhi maka sisa kuota dialihkan ke jalur zonasi atau jalur prestasi.

Calon peserta didik hanya dapat memilih 1 jalur dari 3 jalur pendaftaran PPDB dalam satu zonasi. Selain melakukan pendaftaran PPDB melalui jalur zonasi sesuai dengan domisili dalam zonasi yang telah ditetapkan, calon peserta didik dapat melakukan pendaftaran PPDB melalui jalur prestasi di luar zonasi domisili peserta didik. Sekolah yang diselenggarakan oleh Pemerintah Daerah dilarang membuka jalur pendaftaran penerimaan peserta didik baru selain yang diatur dalam Peraturan Menteri ini.

\section{d. Seleksi}

Seleksi Calon PPDB diatur dengan ketentuan antara lain sebagai berikut: ${ }^{17}$

\footnotetext{
${ }^{17}$ Ibid., Pasal 24 sampai dengan Pasal 31
} 
1) Seleksi calon peserta didik baru kelas 1 (satu) SD

Seleksi calon peserta didik baru kelas 1 SD hanya menggunakan jalur zonasi dan jalur perpindahan tugas orang tua/wali. Seleksi calon peserta didik baru kelas 1 SD mempertimbangkan kriteria dengan urutan prioritas sebagai berikut:

a) Usia

b) Jarak tempat tinggal terdekat ke Sekolah dalam zonasi yang ditetapkan oleh Pemerintah Daerah kabupaten/ kota.

Sekolah wajib menerima peserta didik yang berusia 7 tahun dengan domisili dalam zonasi yang telah ditetapkan. Jika usia calon peserta didik sama, maka penentuan peserta didik didasarkan pada jarak tempat tinggal calon peserta didik yang terdekat dengan Sekolah. Dalam seleksi calon peserta didik baru kelas 1 SD tidak dilakukan tes membaca, menulis, dan berhitung.

2) Seleksi calon peserta didik baru kelas 7 (tujuh) SMP

Seleksi calon peserta didik baru kelas 7 SMP menggunakan jalur zonasi, jalur prestasi, dan jalur perpindahan tugas orang tua/wali. Seleksi calon peserta didik baru kelas 7 SMP yang menggunakan mekanisme daring dilakukan dengan memprioritaskan jarak tempat tinggal terdekat ke Sekolah dalam zonasi yang ditetapkan. Jika jarak tempat tinggal calon peserta didik dengan Sekolah sama, maka yang diprioritaskan adalah peserta didik yang mendaftar lebih awal.

Seleksi calon peserta didik baru kelas 7 SMP yang menggunakan mekanisme luring, dilakukan dengan memprioritaskan jarak tempat tinggal calon peserta didik yang terdekat dengan Sekolah dalam zonasi yang ditetapkan. Untuk daya tampung terakhir dari sisa kuota jalur zonasi, jika terdapat calon peserta didik yang memiliki jarak tempat tinggal dengan Sekolah sama, maka dilakukan dengan memprioritaskan peserta didik yang memiliki nilai ujian Sekolah berstandar nasional lebih tinggi.

3) Seleksi calon peserta didik baru kelas 10 (sepuluh) SMA 
Seleksi calon peserta didik baru kelas 10 SMA menggunakan jalur zonasi, jalur prestasi, dan jalur perpindahan tugas orang tua/wali. Seleksi calon peserta didik baru kelas 10 SMA yang menggunakan mekanisme daring, dilakukan dengan memprioritaskan jarak tempat tinggal terdekat ke Sekolah dalam zonasi yang ditetapkan. Jika jarak tempat tinggal calon peserta didik dengan sekolah sama, maka yang diprioritaskan adalah peserta didik yang mendaftar lebih awal.

Seleksi calon peserta didik baru kelas 10 SMA yang menggunakan mekanisme luring, dilakukan dengan memprioritaskan jarak tempat tinggal calon peserta didik yang terdekat dengan Sekolah dalam zonasi yang ditetapkan. Untuk daya tampung terakhir dari sisa kuota jalur zonasi, jika terdapat calon peserta didik yang memiliki jarak tempat tinggal dengan Sekolah sama, maka dilakukan dengan memprioritaskan peserta didik yang memiliki nilai UN lebih tinggi.

\section{e. Daftar Ulang}

Daftar ulang dilakukan oleh calon peserta didik baru yang telah diterima untuk memastikan statusnya sebagai peserta didik pada Sekolah yang bersangkutan.

Berdasarkan pengaturan yang telah ditetapkan dalam Permendikbud RI No 20 Tahun 2019, maka dapat dilakukan analisis yang akan diuraikan berikut ini.

Perlu diketahui sebelumnya bahwa kebijakan sistem zonasi ini lahir sejak tahun 2017 yang lalu melalui Permendikbud RI No 17 Tahun 2017. Kebijakan sistem zonasi ini tampak terjadi bongkar pasang, betapa tidak setahun berikutnya dilakukan revisi melalui Permendikbud RI No 14 Tahun 2018. Selang beberapa bulan kembali direvisi kembali melalui Permendikbud RI No 51 Tahun 2018, hingga akhirnya dilakukan perubahan melalui Permendikbud RI No 20 Tahun 2019.

Bertitik tolak dari kenyataan tersebut di atas, memang telah terjadi bongkar pasang kebijakan sistem zonasi dalam penerimaan peserta didik baru. Dalam hal ini sesungguhnya terlihat jelas kegagapan pemerintah 
untuk mengatakan ketidaksiapan pemerintah dalam hal ini adalah Kementrian Pendidikan Kebudayaan, sehingga menyebabkan calon peserta didik dan para orang tua, cemas, dan kebingungan.

Apabila dicermati dengan seksama, pemerintah dengan mengeluarkan kebijakan sistem zonasi ini, sesungguhnya tidak memperhatikan peraturan diatasnya, yaitu Peraturan Pemerintah Nomor 13 Tahun 2015 tentang Perubahan Kedua Atas Peraturan Pemerintah Nomor 19 Tahun 2005 tentang Standar Nasional Pendidikan (selanjutnya akan disingkat dengan Peraturan Pemerintah Nomor 13 Tahun 2015) yang merupakan peraturan pelaksana dari UU Nomor 20 Tahun 2003. Berikut adalah ulasannya.

Bertitik tolak dari ketentuan-ketentuan yang telah dipaparkan tersebut di atas, maka dapat diketahui bahwa ketentuan tentang sistem penerimaan peserta didik baru dalam Permendikbud RI No 20 Tahun 2019 bertentangan dengan peraturan diatasnya yaitu PP RI No. 13 Tahun 2015 yang merupakan penjabaran dari UU No 20 Tahun 2003 tentang Sistem Pendidikan Nasional.

Dalam Permendikbud RI No. 20 Tahun 2019 tepatnya Pasal 26 mengatur bahwa zonasi digunakan sebagai dasar untuk pertimbangan seleksi masuk jenjang pendidikan berikutnya. Artinya bahwa dalam pasal ini menetapkan penentuan calon peserta didik yang dapat lolos seleksi dalam penerimaan peserta didik baru menggunakan dasar pertimbangan zonasi, yang mana calon peserta didik baru akan diterima dengan didasarkan pada prioritas jarak tempat tinggal calon peserta didik yang terdekat dengan Sekolah. Dan apabila daya tampung terakhir dari sisa kuota jalur zonasi, jika terdapat calon peserta didik yang memiliki jarak tempat tinggal dengan Sekolah sama, maka dilakukan dengan memprioritaskan peserta didik yang memiliki nilai ujian Sekolah berstandar nasional lebih tinggi.

Sedangkan dalam PP Nomor 13 Tahun 2015 tepatnya Pasal 68 huruf b mengatur bahwa hasil ujian nasional yang digunakan sebagai dasar 
untuk perimbangan seleksi masuk jenjang pendidikan berikutnya. Artinya bahwa penentuan calon peserta didik yang dapat lolos seleksi dalam penerimaan peserta didik baru menggunakan dasar pertimbangan Ujian Nasional semata dan tidak dikenal zonasi.

Sehubungan dengan hal tersebut di atas apabila terdapat peraturan perundang-undangan yang tidak sesuai seperti terjadi pada Permendikbud RI No. 20 Tahun 2019 dengan PP RI No. 13 Tahun 2015 yang merupakan penjabaran dari UU RI No. 20 Tahun 2003, maka konsekuensinya harus dicabut, dan apabila tidak dicabut seyogyanya harus dikaji ulang untuk disesuaikan dengan peraturan diatasnya, sehingga tercipta harmonisasi peraturan perundang-undangan. Hal ini selaras dengan ajaran Hans Kelsen.

Hans Kelsen mengungkapkan sebuah ajaran (dogma) yaitu Stufenbautheory yang mengungkapkan bahwa:

"Norma hukum itu berjenjang-jenjang dan berlapis-lapis dalam suatu hierarki tata susunan, di mana suatu norma yang lebih rendah berlaku, bersumber dan berdasar pada norma yang lebih tinggi, norma yang lebih tinggi berlaku, bersumber dan berdasar pada norma yang lebih tinggi lagi, demikian seterusnya sampai pada suatu norma yang tidak dapat ditelusuri lebih lanjut dan bersifat hipotesis dan fiktif, yaitu norma dasar (Grundnorm)". ${ }^{18}$

Inspirasi Teori Perjenjangan (Stufenttheory) norma hukum Hans Kelsen diilhami oleh seorang muridnya yang bernama Adolf Merkl yang mengemukakan bahwa suatu norma hukum itu selalu mempunyai dua wajah (das doppeltte rechsantlizst). Menurut Adolf Merkl :

"Suatu norma hukum itu ke atas bersumber dan berdasar pada norma yang diatasnya, tetapi ke bawah ia juga menjadi dasar dan menjadi sumber bagi norma hukum dibawahnya, sehingga suatu norma hukum itu mempunyai masa berlaku (rechtskracht) yang relatif oleh karena masa berlakunya suatu norma hukum itu tergantung pada norma hukum yang berada diatasnya, sehingga apabila norma hukum yang berada diatasnya dicabut atau dihapus, maka norma-norma hukum yang berada dibawahnya tercabut atau terhapus pula". ${ }^{19}$

\footnotetext{
${ }^{18}$ Hans Kelsen, General Theory of Law State (New York: Russell \& Russell, 1945), hal 113

${ }^{19}$ Ibid.
} 
Berdasarkan teori Adolf Merkl tersebut, dalam teori jenjang normanya Hans Kelsen juga mengemukakan bahwa suatu norma hukum itu selalu berdasar dan bersumber pada normma yang diatasnya, tetapi ke bawah norma hukum itu juga menjadi sumber dan menjadi dasar bagi norma lebih rendah daripadanya. Dengan demikian dalam hal susunan/hirarki sistem norma, norma yang tertinggi (norma dasar) itu menjadi tempat bergantungnya norma-norma dibawahnya sehingga apabila norma dasar berubah, maka akan menjadi rusaklah sistem norma yang berada dibawahnya.

Teori Jenjang Norma Stufenbautheory Hans Kelsen dikembangkan ke dalam tatanan kenegaraan (ranah hukum tata negara) oleh muridnya Hans Nawiasky dalam bukunya yang berjudul Allgemeine Rechtslehre mengemukakan bahwa sesuai dengan teori Hans Kelsen:

"Suatu norma hukum dari negara manapun selalu berlapis-lapis dan berjenjang-jenjang di mana norma yang berada di bawah berlaku, berdasar dan bersumber pada norma yang lebih tinggi, norma yang lebih tinggi berlaku, berdasar dan bersumber pada norma yang lebih tinggi lagi, sampai pada suatu norma yang tertinggi yang disebut norma dasar, tetapi Hans Nawiasky juga berpendapat bahwa selain norma itu berlapis-lapis dan berjenjang, norma hukum dalam suatu negara itu juga berkelompok-kelompok". ${ }^{20}$

Berdasarkan uraian tersebut, maka dapat disimpulkan bahwa Stufenbautheory dari Hans Kelsen diterapkan juga di Negara Indonesia, yang mana di Negara Indonesia diterjemahkan melalui UU RI No. 12 Tahun 2011 tentang Pembentukan Peraturan Perundang-undangan, yang didalamnya diatur tentang tata hierarki peraturan perundang-undangan yang berjenjang-jenjang dan berlapis-lapis dalam suatu hierarki tata susunan peraturan perundang-undangan, dengan konsekuensi suatu norma yang lebih rendah berlaku, bersumber dan berdasar pada norma yang lebih tinggi, norma yang lebih tinggi berlaku, bersumber dan berdasar pada norma yang lebih tinggi lagi, demikian seterusnya sampai pada suatu

\footnotetext{
${ }^{20}$ Ibid.
} 
norma yang tidak dapat ditelusuri lebih lanjut dan bersifat hipotesis dan fiktif, yaitu norma dasar yaitu Pancasila yang menjadi roh UUD NRI Tahun 1945, sehingga oleh karena Permendikbud RI No. 20 Tahun 2019 dengan PP RI No. 13 Tahun 2015 yang merupakan penjabaran dari UU No. 20 Tahun 2003 tentang Sistem Pendidikan Nasional kedudukannya lebih rendah, maka konsekuensinya harus dicabut, dan apabila tidak dicabut seyogyanya harus dikaji ulang untuk disesuaikan dengan peraturan diatasnya, sehingga tercipta harmonisasi peraturan perundang-undangan.

Berdasarkan analisis yang telah dipaparkan tersebut di atas, maka dapat diketahui bahwa pengaturan sistem zonasi dalam PPDB yang diatur berdasarkan Permendikbud RI No 20 Tahun 2019 tepatnya Pasal 26, bertentangan dengan peraturan diatasnya yaitu PP RI No 13 Tahun 2015, tepatnya Pasal 68 huruf b yang menetapkan bahwa hasil ujian nasional digunakan sebagai dasar untuk pertimbangan seleksi masuk jenjang pendidikan berikutnya, yang mana peraturan pemerintah ini merupakan penjabaran dari UU RI No 20 Tahun 2003. Sehingga berdasarkan Stufenbautheory dari Hans Kelsen yang diterjemahkan di Indonesia melalui UU RI No. 12 Tahun 2011 maka Permendikbud RI No 20 Tahun 2019 harus dicabut, atau perlu dikaji ulang dan disesuaikan dengan peraturan diatasnya agar tercipta harmonisasi peraturan perundang undangan.

\section{Implikasi Bagi Calon Peserta Didik Mengenai Pengaturan Tentang Sistem}

\section{Zonasi Dalam Penerimaan Peserta Didik Baru Berdasarkan Permendikbud RI Nomor 20 Tahun 2019}

Sehubungan dengan pengaturan tentang tentang sistem zonasi PPDB, tentu akan menimbulkan berbagai implikasi, terutama bagi sasaran atau objek kebijakan, yaitu Calon Peserta Didik. Menurut Dye, implikasi kebijakan adalah keseluruhan efek yang ditimbulkan oleh suatu kebijakan dalam kondisi kehidupan nyata. Lebih lanjut, Winarno menyatakan bahwa implikasi dari suatu kebijakan mempunyai beberapa dimensi dan semuanya harus diperhitungkan ketika membicarakan evaluasi. Berikut ini dimensi dari suatu 
dampak kebijakan:

1. Dampak kebijakan terhadap situasi dan kelompok - kelompok target atau orang-orang yang terlibat (intended and unitended consequences).

2. Dampak kebijakan terhadap situasi dan kelompok - kelompok di luar sasaran atau tujuan kebijakan (externalities or spilover effect)

3. Dampak kebijakan pada keadaan-keadaan sekarang dan di masa yang akan datang (untuk melihat konsekuensi-konsekuensi yang ditimbulkan adanya kebijakan berdasarkan dimensi waktu, yakni masa sekarang atau masa yang akan datang)

4. Biaya langsung yang dikeluarkan untuk membiayai program-program kebijakan publik

5. Biaya tidak langsung yang ditanggung oleh masyarakat atau beberapa anggota masyarakat akibat adanya kebijakan publik. ${ }^{21}$

Dari kelima dampak yang disampaikan oleh Winarno tersebut, maka dalam penelitian ini akan difokuskan pada dampak kebijakan terhadap situasi dan kelompok - kelompok target (intended) yaitu calon peserta didik. Dengan adanya kebijakan sistem zonasi pada PPDB maka terdapat implikasi positif maupun negatif yaitu sebagai berikut:

1. Implikasi Positif

a. Kemudahan Akses Pendidikan

Sistem zonasi pada PPDB mengatur lebih merata pada lulusan sekolah disetiap jenjang pendidikan untuk dapatkan akses sekolah. Dengan memperhitungkan jarak sekolah dan tempat tinggal, serta rasio daya tampung yang ideal, sehingga para calon peserta didik memiliki kesempatan yang sama untuk melanjutkan pendidikan di jenjang selanjutnya.

b. Pemerataan Pendidikan

Melalui sistem zonasi ini tidak ada lagi sekolah favorit, karena semua peserta didik hanya diperkenankan melanjutkan pendidikannya

${ }^{21}$ Budi Winarno. Kebijakan Publik Teori, Proses dan Studi Kasus (Jogyakarta: Center of Academic Publishing Service, 2014), hal 197 
Permendikbud RI No 20 Tahun 2019 memberikan ruang bagi peserta didik untuk daftar pada sekolah dengan kuota 80 persen berdasarkan zonasi, 15 persen berdasarkan prestasi dan 5 persen berdasarkan perpindahan orang tua / wali.

\section{Implikasi Negatif}

a. Calon Peserta didik tidak bisa memilih sekolah yang sesuai harapan

Peserta didik tidak memiliki pilihan terbaik untuk mendapatkan tempat belajar yang sesuai harapan. Terlebih lagi jumlah sekolah yang memiliki kualitas baik masih jauh dari harapan, akibatnya calon peserta didik yang memiliki kualitas baik dan berprestasi, terpaksa harus mendapatkan pendidikan di tempat yang tidak berkualitas.

b. Kurangnya penghargaan terhadap calon peserta didik yang berprestasi

Dalam PPDB yang diatur berdasarkan Permendikbud RI No 20 Tahun 2019 yang menggunakan standar PPDB dengan zonasi, sangat merugikan calon peserta didik baru yang mempunyai kualitas nilai Ujian Nasional yang baik dan berprestasi, karena pihak sekolah akan memprioritaskan jarak dekat rumah daripada prestasi. Bisa jadi bahkan yang berprestasi tidak mendapatkan sekolah negeri karena jarak rumahnya tidak dalam lingkaran zonasi yang ditetapkan pemerintah yang disebabkan belum meratanya sekolah negeri dalam suatu wilayah tertentu.

Berdasarkan uraian tersebut di atas, maka dapat diketahu bahwa implikasi bagi calon peserta didik mengenai pengaturan tentang sistem zonasi dalam PPDB berdasarkan Permendikbud RI Nomor 20 Tahun 2019, meliputi 2 (dua) hal yaitu: Pertama, implikasi positif antara lain calon peserta didik baru memperoleh akses pendidikan dan terjadinya pemerataan pendidikan; Kedua, implikasi negatif antara lain calon peserta didik baru tidak bisa memilih sekolah yang sesuai harapan, dan bagi calon peserta didik yang berprestasi kurang mendapat penghargaan. 


\section{E. PENUTUP}

Pengaturan sistem zonasi dalam PPDB yang diatur berdasarkan Peraturan Menteri Pendidikan Dan Kebudayaan Republik Indonesia Nomor 20 Tahun 2019 tepatnya Pasal 26, bertentangan dengan peraturan diatasnya yaitu PP RI No 13 Tahun 2015 tepatnya Pasal 68 huruf b yang menetapkan bahwa hasil ujian nasional digunakan sebagai dasar untuk pertimbangan seleksi masuk jenjang pendidikan berikutnya, yang mana peraturan pemerintah ini merupakan penjabaran dari Undang-Undang Nomor 20 Tahun 2003 tentang Sistem Pendidikan Nasional. Sehingga berdasarkan Stufenbautheory dari Hans Kelsen yang diterjemahkan di Indonesia melalui Undang - Undang Nomor 12 Tahun 2011 maka Peraturan Menteri Pendidikan Dan Kebudayaan Republik Indonesia Nomor 20 Tahun 2019 harus dicabut, atau perlu dikaji ulang dan disesuaikan dengan peraturan diatasnya agar tercipta harmonisasi peraturan perundang undangan.

Implikasi bagi calon peserta didik mengenai pengaturan tentang sistem zonasi dalam PPDB berdasarkan Permendikbud RI Nomor 20 Tahun 2019, meliputi 2 hal yaitu: Pertama, implikasi positif antara lain calon peserta didik baru memperoleh akses pendidikan dan terjadinya pemerataan pendidikan; Kedua, implikasi negatif antara lain calon peserta didik baru tidak bisa memilih sekolah yang sesuai harapan, dan bagi calon peserta didik yang berprestasi kurang mendapat penghargaan. 


\section{DAFTAR PUSTAKA}

\section{BUKU}

Amirin, Tatang A. Menyusun Rencana Penelitian. Jakarta, C.V. Rajawali, 1986

Bahrudin. Manajemen Peserta Didik, Jakarta, Indeks, 2014.

Hasbullah, M. Kebijakan Pendidikan, Jakarta, Raja Grafindo Persada, 2015

Ibrahim, Johnny. Teori Dan Metodologi Penelitian Hukum Normatif, Edisi Revisi, Malang, Bayumedia Publishing, 2005.

Imron, Ali. Manajemen Peserta Didik, Jakarta: Bumi Aksara, 2011.

Marzuki, Peter Mahmud. Penelitian Hukum, Jakarta, Kencana, 2006.

Rahardjo, Mudjia. Pemikiran Kebijakan Pendidikan Kontemporer, Malang, UIN Maliki Perss, 2010.

Rohman, Arif dan Imanto, Teguh. Education Policy In Desentralization Era, Yogyakarta, Pustaka Pelajar, 2010

Soekanto, Soerjono. Pengantar Penelitian Hukum, Jakarta, Universitas Indonesia, 1995.

Sunggono, Bambang. Metode Penelitian Hukum, Jakarta, PT. Raja Grafindo Persada, 2002.

Tilaar, H.A.R. dan Nugroho, Riant. Kebijakan Pendidikan: Pengantar Untuk Memahami Kebijakan Pendidikan dan Kebijakan Pendidikan Sebagai Kebijakan Publik, Yogyakarta: Pustaka Pelajar, 2009.

Tim Dosen Administrasi Pendidikan UPI, Manajemen Pendidikan, Bandung, Alfabeta, 2009.

Winarno, Budi. Kebijakan Publik Teori, Proses dan Studi Kasus. Jogyakarta, Center of Academic Publishing Service, 2014.

\section{JURNAL}

Dian Purwanti, Ira Irawati, Josy Adiwisastra, Efektivitas Kebijakan Penerimaan Peserta Didik Baru Sistem Zonasi Bagi Siswa Rawan Melanjutkan Pendidikan, Jurnal Ilmiah Ilmu Administrasi Negara Dinamika Vol 5 No 4, Universitas Galuh, 2019, Ciamis.

DOI: http://dx.doi.org/10.25157/dinamika.v5i4.1737

Muhamad Khoirul Umam, Peningkatan Mutu PendidikanMelalui Manajemen Peserta Didik, Jurnal al-Hikmah Vol. 6 no. 2 Oktober 2018, STAI Badrus Sholeh Kediri, 2018, Kediri,

Nurkholis, Pendidikan Dalam Upaya Memajukan Teknologi, Jurnal Kependidikan, Vol. 1 No. 1 Edisi November 2013. DOI: https://doi.org/10.24090/jk.v1i1.530

Wahyuni, Dinar, Pro dan Kontra Sistem Zonasi Penerimaan Peserta Didik Baru Tahun Ajaran 2018/2019, Jurnal Info Singkat, Vol. X, No.14/II/Puslit/Juli 2018. 
e-ISSN : 2621-4105

\section{KARYA ILMIAH}

Latifatul Khasanah, Umi. Tesis: Analisis Implementasi Kebijakan Sistem Zonasi Perspektif Stakeholder Sekolah (Studi Multisitus di SMP Negeri 1 Malang dan SMP Negeri 3 Malang Di Kota Malang). Program Magister Manajemen Pendidikan Islam. Pascasarjana Universitas Islam Negeri Maulana Malik Ibrahim, Malang, 2018.

\section{UNDANG-UNDANG}

Sekretariat Negara RI. Undang-Undang Dasar Negara Republik Indonesia Tahun 1945. Jakarta, 2002.

----------Undang-Undang Nomor 20 Tahun 2003 tentang Sistem Pendidikan Nasional. Jakarta, 2003.

----------Peraturan Pemerintah Nomor 17 Tahun 2010 tentang Pengelolaan dan Penyelenggaraan Pendidikan. Jakarta, 2003.

--Peraturan Pemerintah Nomor 13 Tahun 2015 tentang Perubahan Kedua Atas Peraturan Pemerintah Nomor 19 Tahun 2005 tentang Standar Nasional Pendidikan. Jakarta, 2015.

---Peraturan Presiden Nomor 14 Tahun 2015 tentang Kementerian Pendidikan dan Kebudayaan sebagaimana telah diubah dengan Peraturan Presiden Nomor 101 Tahun 2018 tentang Perubahan atas Peraturan Presiden Nomor 14 Tahun 2015 tentang Kementerian Pendidikan dan Kebudayaan. Jakarta, 2015.

Sekretariat Menteri RI. Peraturan Menteri Pendidikan Dan Kebudayaan Republik Indonesia Nomor 17 Tahun 2017 tentang Penerimaan Peserta Didik Baru Pada Taman Kanak-Kanak, Sekolah Dasar, Sekolah Menengah Pertama, Sekolah Menengah Atas, Sekolah Menengah Kejuruan, Atau Bentuk Lain Yang Sederajat. Jakarta, 2017.

---Peraturan Menteri Pendidikan Dan Kebudayaan Republik Indonesia Nomor 14 Tahun 2018 tentang Penerimaan Peserta Didik Baru Pada Taman Kanak-Kanak, Sekolah Dasar, Sekolah Menengah Pertama, Sekolah Menengah Atas, Sekolah Menengah Kejuruan, Atau Bentuk Lain Yang Sederajat. Jakarta, 2018.

---Peraturan Menteri Pendidikan Dan Kebudayaan Republik Indonesia Nomor 51 Tahun 2018 tentang Penerimaan Peserta Didik Baru Pada Taman Kanak-Kanak, Sekolah Dasar, Sekolah Menengah Pertama, Sekolah Menengah Atas, Dan Sekolah Menengah Kejuruan. Jakarta, 2018.

---Peraturan Menteri Pendidikan Dan Kebudayaan Republik Indonesia Nomor 20 Tahun 2019 tentang Perubahan Atas Peraturan Menteri Pendidikan Dan Kebudayaan Nomor 51 Tahun 2018 tentang Penerimaan Peserta Didik Baru Pada Taman Kanak-Kanak, Sekolah Dasar, Sekolah Menengah Pertama, Sekolah Menengah Atas, Dan Sekolah Menengah Kejuruan. Jakarta, 2019. 


\section{INTERNET}

Dosen Pendidikan. Pengertian Siswa Menurut Para Ahli (https://www.dosenpendidikan.co.id/pengertian-siswa-menurut-paraahli/diakses 06 September 2019), 2019.

Gelar Gandarasa. PPDB 2019, Belum Semua Sekolah Kuotanya Terpenuhi (https://www.pikiran-rakyat.com/pendidikan/2019/06/25/ppdb-2019-belumsemua-sekolah-kuotanya-terpenuhi/, diakses 05 September 2019), 2019.

Guru Pendidikan. Pengertian Pendidikan Menurut Para Ahli : Tujuan, Fungsi \& Jenisnya Terlengkap (https://seputarilmu.com/2019/01/pengertianpendidikan-menurut-para-ahli.html/,diakses 06 September 2019), 2019.

Zaky. Pengertian Pendidikan Menurut Para Ahli dan Secara Umum (https://www.zonareferensi.com/pengertian-pendidikan/,diakses, $\quad 06$ September 2019), 2019

Informasi Pendidikan dan Kebudaaan. Pengertian Peserta Didik Menurut Beberapa Ahli. Silabus.web.id 